\title{
How Can Large Foreign-Funded Supermarkets Gain a Foothold in China: Take Sam's Club as a Study Case
}

\author{
Hailin Cheng ${ }^{1, *, \dagger}$, , Yufei Cheng ${ }^{2, *}, \dagger$, Yue $\mathrm{Xu}^{3,{ }^{*}, \dagger}$ \\ ${ }^{1}$ Finance, University of Manchester, UK \\ ${ }^{2}$ Marketing, Newcastle University, UK \\ International Business, University of Leeds, UK \\ *Corresponding author: guanghua.ren@gecacdemy.cn \\ tThese authors contributed equally.
}

\begin{abstract}
Sam's Club is one of the largest membership-based retailers in the world. In the context of the epidemic, they still have a place in China's retail industry. Moreover, it has won the affirmation of many customers through its unique advantages and innovations. This paper aims to use Sam's Club as the main object of this case study to analyze how it has won in the Chinese retailer industry. SWOT Analysis is preferred to use as the primary method. This paper concludes that the differentiated and high-quality private label allows Sam's Club to win some competitiveness. And in the context of economic growth and the COVID-19, consumers are more inclined to buy a larger quantity of goods for storage at a time, which also reflects the advantages of Sam's Club. On the other hand, Chinese policy will impose some restrictions on Sam's Club. Therefore, Sam's Club in the Chinese market needs to pay more attention to the Chinese government's policies on international supermarkets and actively adjust and innovate policies to enhance competitiveness and increase customer loyalty in line with international conditions.
\end{abstract}

Keywords: Sam's Club, Marketing Mix, International Business

\section{Introduction}

With the development of globalization, entering into foreign countries is an inevitable trend for enterprises to gain more reputation and earn more profits. China is one of the largest and most potential economies that attract them to expand for multinational retail companies. During COVID19, the Chinese market obtains tremendous opportunities with inelastic consumer demands since people tend to store a large volume of goods to guarantee their livelihood. However, the current performances of multinational retailers like Walmart, Metro, Carrefour, and other famous foreign enterprises in China is not satisfying. Many companies have sold their Chinese business to local companies. For example, in 2019, German retailer Metro sold its business to Wumei to quit the Chinese market due to its dropping revenue [1]. Walmart, the biggest retail company globally, has had to close nearly 80 Chinese stores from 2016 to 2020 to prevent their general financial loss [2]. The changing consumer demand and fierce competition from e-commerce may account for the failure of foreign companies.

In the new Chinese market, the reform of the retail industry has become a central issue for multinational retailers. To better adapt to the consumers' preference for rising living standards, Walmart has accelerated the expansion of Sam's club that membership stores targeted middle-end consumers in China in recent years. This type of store provides high-quality products from about 30 brands worldwide and services that some food can be directly delivered to the home for consumers who pay $¥ 260$ a year for a membership fee to be allowed to enter and shop [3]. Recently, this operating pattern turned out to be a success with a $4 \%$ increased operating revenue and 2 million loyal members [3]. Previous studies have reported more about strategies, operating patterns and international business of traditional retail foreign enterprises that provide various ranges of cost-effective goods for consumers. However, few authors discuss membership stores.

Some researchers have already conducted multiple studies to analyze Sam's Club from different dimensions. For instance, Kim and Choi, in 2007 have researched the role of warehouse membership 
fees in the competition of retailing industry [4]; Courtemanche and Carden, in 2014, compared and contrasted Costco and Sam's Club [5]. However, there is still a knowledge gap created by the lack of studies on the reasons for the success of international retailers in foreign countries. This is because western firms were established under a different context of China, public and academies would be more eager to analyze the process of adaptation and transformation that they have experienced after entered the Chinese market, rather than identifying the factors behind their fruits of victory, especially the later question would require years of studying and following up. However, today, since more and more international retailing business starts to expand overseas, it is crucial to study from the previous cases of internationalization to accumulate experience and recognize factors that contribute to the success of a business in a foreign country. Therefore, since it is necessary to fulfill the existing knowledge gap, this essay will use Sam's Club as the main object of this case study to analyze how it has won in the Chinese retailer industry. As previous studies have provided a knowledge base of the product network, paid membership system, and international competition inside the retailing industry, this case study will use these studies as a knowledge base to value the business strategy of Sam's Club in China. The main objective of this paper is to determine the factors of its victory by identifying how the four elements of the marketing mix could influence the operation outcomes of international business. The research question of this paper is important because it could help firms survive and succeed under intense competition in the Chinese retailing industry and then give an insight to international businesses looking forward to entering an attractive Chinese market. There are several motivations for this study. First, the application of annual membership by the foreign retailer is a rare and relatively new system during recent years in China, which makes it interesting to analyze how the membership affects Chinese consumers' shopping experience and preferences. Also, Sam's Club leaves Chinese consumers a strong impression of its products and stores by using media to advertise, and it also attracts researchers' interest. In addition, another business, whose name is Wal-Mart Supercentre, is also run by Sam's Club's owner, Wal-Mart, which has already failed in China. It is worthy to carry out some studies to understand what the unique factors of Sam's Club enable it to grow sustainably in China, rather than an end in such anti-climax as its fellow business.

\section{Literature Review}

\subsection{International Business}

Over the past decade, an increasing number of essays have paid more attention to international business. In 1960, economist Hymer firstly contributed to shifting the discussion from a foreign direct investment based on capital flow theory to the firm level as the first starter of the modern theory of the multinational enterprise [6]. Thus, the firm was in the central role of international business and foreign investment analysis. Then, between 1977 the Swedish authors Johanson and Vahlne put forward the process model of internationalization to link to the firm's behaviour, which explained that internationalization was about economy and business strategies, organizational behaviour, polities, and cultures [7]. After, Turnbull and Valla discussed the importance of the business network that helps firms establish long-term relationships with suppliers and consumers in international business [8]. To fill the gap of Hymer's theory that he viewed the external environment of multinational companies as a closed system, the contingency theory empathized the impact of changing environment on the performances of firms that multinational enterprises should adapt their strategies to the foreign environment they related to [9]. Forsgren also developed further, and he mentioned the flexible management between headquarters and subsidiaries that it was vital to leave autonomous priority for decision-making of subsidiaries under coordinated mission and value [10]. Furthermore, the evolutionary theory of the multinational enterprise demonstrated that corporate should sustain their competitive advantage and core competence through any subsidiaries and cooperation [11]. Finally, Engwall proposed the Institutionalization theory that multinational enterprises play an essential role in shaping countries' institutional contexts, which also influences firms. Therefore, the importance of multinational enterprises to adapt to the culture and society of countries can be 
examined [12]. Overall, these studies outline a critical role for multinational enterprises to recognize the changing of the local context of different countries and have complete financial and strategic capacity to prepare and manage for adapting to these changes flexibly, which is an essential factor to their success.

\subsection{Marketing Mix}

A marketing mix is a set of marketing tools used by companies to pursue the objectives and goals of the business; each element of the framework can impact consumer demand. It was firstly presented by Neil Borden in 1964 and had twelve elements at the beginning. By employing the framework for marketing management, a profitable business would be created if all the controllable factors of the mix were well-controlled [13]. Then, Jerome McCarthy conducted further studies related to the concept and simplified the elements by reducing the factors to a four-element framework that includes price, product, promotion, and place. Today, marketing mixes soon became one of the most popular and indispensable marketing tools practised by both business managers and academics. The concept includes a list of important elements in which the marketing projects are consistent. The managers could adjust his or her research and strategy design according to the force of these ingredients to do a successful business [13]. When formulating the elements of marketing mixes, managers take account of broadened forces that would govern the individual elements of the theory, including a range of behavioural forces such as consumer behaviours, trader's behaviour, competitor's position, and behaviour and government controls [13]. In this essay, the simple four-element framework of the marketing mix will be used to analyze the object of the case study and answer the research question. The four components of the marketing mix, which are product, price, promotion, and place, respectively, also have an individual impact on the international business strategy of Sam's Club. Thus it is crucial to determine their concepts.

\subsubsection{Product}

A product is defined as either a physical item or service offered to consumers that they would like to purchase. It can be either intangible, like a cleaning service, or material, such as furniture and clothing. The importance of this element is emphasized because products and services are brought to the public to gain attention and satisfy consumers' needs. It is also one of the major revenue streams of retailing companies. In terms of consumers' motives, it is the trader's responsibility to be able to differentiate the goods and services from rivals to stimulate potential customers' perception to value the products as worth purchasing [14]. As motives drive consumers' decisions, factors like brand equity and brand trust would significantly impact the decision-making progress. Furthermore, the individual consumer could ask for more information to understand the products or service more diverse, such as the durability, function, and benefits. For instance, technological innovation could have a decisive impact on customers who have a deep interest in technology or work in a related field. Thus, it is suggested by researchers that products could change consumers' motives.

\subsubsection{Price}

Price is a fair assessment and evaluation of products and services that consumers would be willing to pay since it can increase sales revenue and company market share; many scholars suggest price is the most important among the four elements. It is worth noting that prices are dependent on the volume of products and have an inverse relationship with the number of sales. Therefore the business needs to find a suitable pricing strategy and take comprehensive factors into account, such as costplus, value basis, external competition, input size, discount and consumer's psychology. Price also has a significant impact on consumers' motives because customers will value the cost performance of money when shopping, especially for highly price-sensitive products. Sometimes, consumers' purchasing options will also be affected by the price level if they believe there is a correlation between the prices and the quality of goods. 


\subsubsection{Place}

The place is the process of distribution and movement by which products and services reach consumers. The distribution channel involves services or products providers, agents, and customers. The forms of places can vary from physical location to online stores. The term of location also refers to the distance from the consumer to the stores and the surroundings. The atmosphere of stores would have influence consumers' experience in-stores, which would change their motives of visiting [14].

\subsubsection{Promotion}

Promotion can increase consumers' awareness of products and services so that higher sales volume is more likely to be achieved. There is a wide range of consumer sales promotion tools, such as direct marketing, advertising, sales promotion, private sales, and public relations. Moreover, an effective promotion strategy should be able to affect consumers' internal impulses by increasing their level of awareness and interest about the products and services to strike imaginations so that their willingness and interests in relevant products and services could be promoted.

\section{Methodology}

\subsection{Research Design}

The methodology that SWOT analysis is applied to attempt to analyze how Membership stores of Walmart operate successfully in China, which focuses on enterprise's strategies. The SWOT analysis examines both internal and external environments to provide relatively comprehensive and appropriate strategies for further development [15]. The internal analysis aims to find out the strength and weaknesses of the company inside, which they can remain more competitive or improve their shortages. The external analysis contains external environment and operations like economic and technological to investigate how these impact on company's performances and how a company can act to these changes to develop further. Since the research object of membership store is relatively new with few case studies and resources to be harnessed, this paper uses a qualitative method to analyze better. To exploit the competitive performance of Sam's Club, SWOT analysis helps reveal both internal and external factors comprehensively. Moreover, many similar articles about international retailers apply this method to analyze, like Chang's paper about the enter mode of retailers in the Chinese market and Chen's articles on the development strategy of the Chinese retail industry [16].

\subsection{Origins of Sam's Club and historical background}

Sam's Club is the membership-only warehouse retailer of Walmart, initially founded by Sam Walton in 1983 [17]. Its business objective is to be the most valuable membership for consumers. It runs a limited-item business model and provides quality products with competitive prices that traditional retail cannot match. After expanding aggressively in its homeland, Sam's Club started its business journey in China in 1996 by opening the first store in Shenzhen. Currently, there are 26 physical stores located in 23 cities, and the number of the store is expected to increase to 45 by the end of 2022 [17]. In China, a store of Sam's Club typically has a sales floor area of approximately 20,000 square meters [17]. Also, it has more than 3 million Chinese members, and the annual membership fee costs 39 dollars [17]. When Sam's Club had just started its business in China, the paid annual membership system was scarce despite several international retailers who entered the Chinese market at the same time as Sam's Club, such as Metro and Pricemart. After years of operation, Sam's Club is the only foreign retailer maintaining paid membership among its peers. When Sam's Club first expanded to China, the sales revenue and performance were not impressive. There were only four stores up to 2011, and the number of stores sharply increased to nineteen in 2010, as Figure 1 shows. This is because the national economic condition has been improved and the prevalence of rational consumption, which means Chinese customers would value the price performance, and the membership system of Sam's Club could fit with the trend. Moreover, since Sam's Club has already 
recognized the future development of internet technology and the popularity of e-commerce, it also constructed online shopping channels and databases in 2010 to serve consumers' demands better. As a result, Sam's Club continues to expand and operates in China successfully with a foreseeable future of the business landscape.

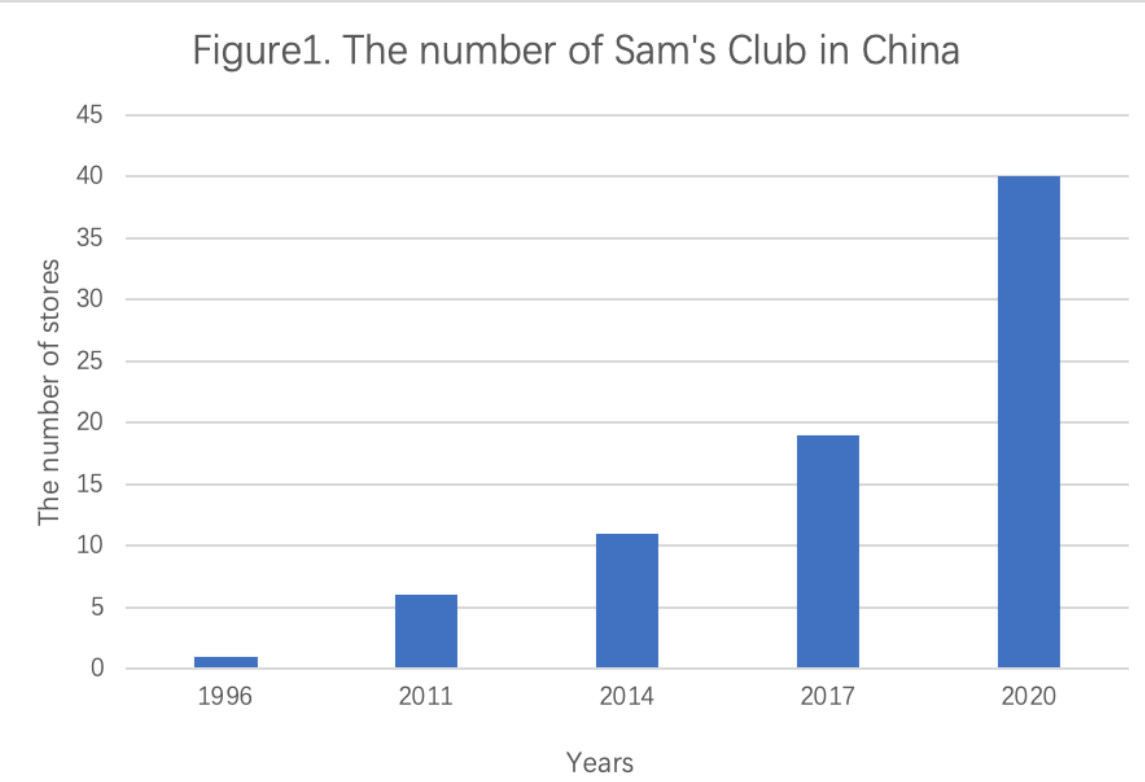

Figure 1. The number of Sam's Club in China

\subsection{SWOT Analysis}

\subsubsection{Strength}

The factor of strength in the SWOT analysis framework means sectors where the business gain competitiveness. Since Sam's Club entered the Chinese market in early 1996, it has focused on its operating strategies of membership stores as they believe the future will be consumer-orientated consumption. This unique operation turns out to be a huge success now. Consumers tend to live a quality life with demanding quality and distinctive goods and services, which they are more likely to pay increased $11 \%$ money on daily consumption [18]. To gain competitive advantages over rivals, Sam's Club concentrates on the quality of the goods that is the product element of the marketing mix that cons3umers will consider purchasing the goods. Based on an international logistics system with various commodities sourcing from worldwide and well information management, Sam's Club can sort out and select the most qualitative and trendy products to provide for consumers. In this case, customers can save time, reduce the risk of choosing dissatisfying products, and purchase trendy goods, which are their recent wants. For instance, semi-cooked food and cooked food are popular among consumers as they want to get tasty and quick food with their limited time for eating. Therefore, Sam's Club provides the zone for these food types and even gets tastier than other marts. As a result, Sam's Club attracts many targeted consumers and retains more loyal consumers. Moreover, cost control is also one merit of Sam's Club: the price factor of the marketing mix. Since people have a more flexible income on consumption, customers are less price-sensitive but care more about brands. Thus, it is an excellent opportunity for the company to open their own brand of the commodity to guarantee its quality and achieve cost-effectiveness. Member's Mark, own running brand, accounts for $30 \%$ of revenue sales to set up standards and control profit for Sam's Club. Occupied with worldwide suppliers resources, Sam's Club can command the quality of raw materials and operation process to be more competitive. Meanwhile, with large economics of scale, it also sets a competitive price for consumers to enjoy the quality goods and control its cost to obtain more profit at the same time. Under the same quality level of products, the cheaper price gains more consumers. The products are more easily heated among the individuals and more consumers want to purchase to boost the 
company's sales. Obtained both competitive product and price, Member's Mark is one of the most popular products in 2021, satisfying an increasing number of consumers to repeat purchase and compete over other rivals, as figure 2 proved.

Figure 2 The sales revenue of Member's Mark in

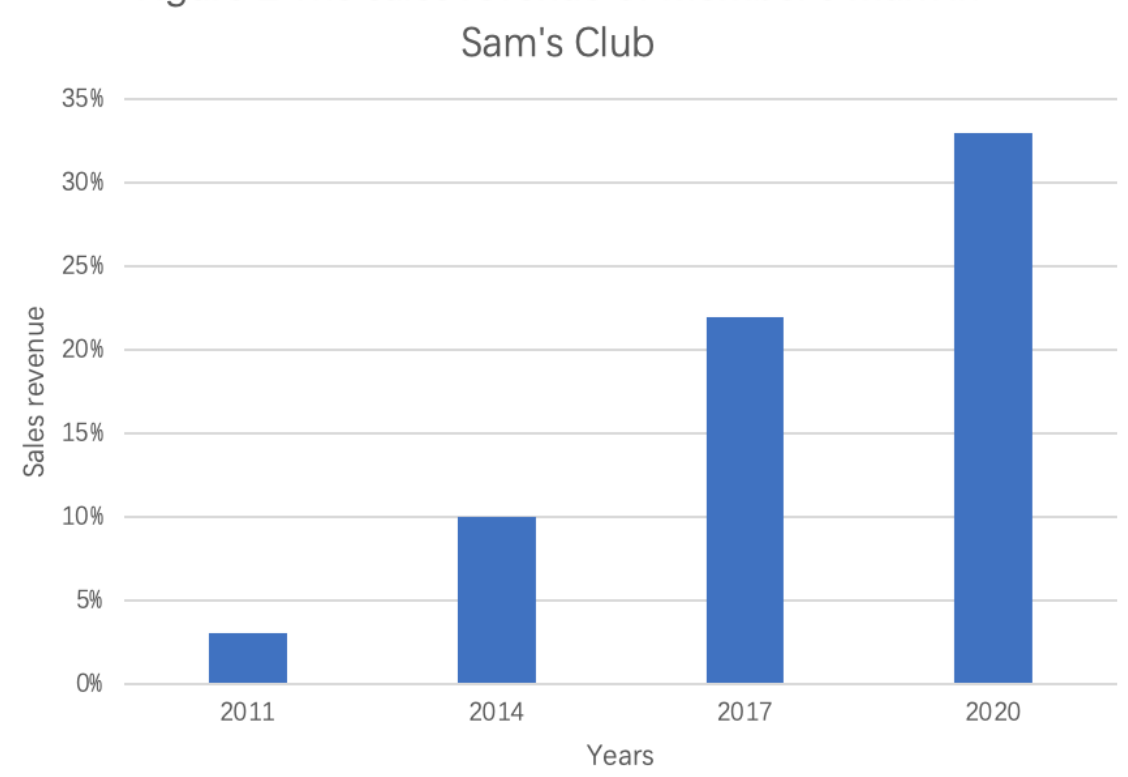

Figure 2. The sales revenue of Member's Mark in Sam's Club

\subsubsection{Weakness}

The area of weakness in the SWOT analysis framework indicates areas where the business should improve in the future. One of the most adverse factors that could impede Sam's Club's expansion in China is the geographical location of the store. As mentioned in the previous part of this paper, the place is one of those important elements of the marketing mix because it can influence consumers' motives in multiple ways. For instance, if products and services can be access and purchase conveniently, consumers will be more likely to find particular items that they need and buy [19]. However, a typical store of Sam's Club in China usually occupies a large floor area, which means the brick-and-mortar store can only be located at remote places. Although the popularizing rate of cars owned by Chinese households is relatively high, the individual consumer will still consider and evaluate the relevant costs associated with shopping at Sam's Club. Fuel bills and time required will be taken into account [20]. In addition, consumers who drive to shop would tend to purchase in bulk, but many Chinese households are families of three people because of past policy on the national population. Thus there would be a ceiling of maximum daily consumption of necessities or other types of goods and services. As a result, some households would prefer nearby shops rather than Sam's Club. The disadvantages of location would reduce consumers' motives to shop at Sam's Club if they are disappointed by the inconveniences and extra costs, resulting in inevitable consumer loss.

\subsubsection{Opportunities}

Firstly, Chinese consumers presently hold a different view of paid membership system than before. Along with the economic growth, personal and household economic condition was also improved, which made the charged membership that once sounded unreasonable for Chinese consumers who were still undergoing the early stage of economic development become more widely accepted. At the same time, more and more customers value the quality of products and services more as the national income has improved. Another opportunity to be mentioned is the impact of the global pandemic on consumers' motives. It is noticeable that the COVID-19, social distance regulation, and lock-down have altered their traditional or usual ways of buying and shopping. Therefore the business should recognize the new buying behaviour of consumers and respond to their changes. For instance, to react 
to the uncertainty of the future daily necessities supply, consumers adapted to stockpile essential products like toilet paper [21], which warehouse retailers can satisfy their needs.

\subsubsection{Threatens}

The major threats faced by Sam's Club in China is the intense competition. International competitors, such as Costco and Metro, and local competitors like Heman, have similar market positioning as Sam's Club, and their products are not highly differentiated. Each of these retailers has its loyal customer groups and wins a good reputation from them. Moreover, local companies have been supported by the Chinese government. For instance, Yonghui supermarket is financially supported and provided tax-free to open their stores around China [22]. While, Sam's Club is restricted on satellite positioning system, operation technology of logistics and burdening more tax, which resulted in high operating cost and lower competitiveness.

\section{Results}

In summary, differentiated and quality products and own brand reputation with both quality and price guaranteeing is Sam's Club's internal competitiveness. Moreover, taking advantage of economic growth and COVID-19, Sam's Club suits consumers changing preferences of pursuing quality goods and behaviour of buying bulk commodities at once, which is the company's external strength to gain more competitiveness to attract more loyal consumers and improve their satisfaction. However, on the other side, the location siting and government policies limit Sam's Club to expand further. The location company chosen brings inconvenience to consumers, which lowers consumers attractiveness. Furthermore, the Chinese government's policies restrict Sam's Club technology and bear more tax, which is not competitive against local rivals.

\section{Discussion}

The SWOT analysis gives a comprehensive examination of how Sam's Club obtains success in China and how it can improve its conditions to be better. The consumers' orientation strategy and operation mode of Membership stores contribute to the success of Sam's Club to obtain millions of loyal consumers. Underlying these strategies, the quality and differentiated goods and own brand commodities with reason price suit consumers changing preferences. Moreover, the economic growth and COVID-19 regulation also help Sam's Club be famous among the consumers to shop. This success indicates that consumers are the key to the company's performance, and the company needs to adjust to consumers changing demands quickly. Therefore, Sam's Club should focus on improving more consumers' satisfaction and being innovative to differentiate its brand from other companies to attract more consumers. It is suggested to develop the department to research consumers' behaviours to be familiar with their switching needs and adjust to the company. Then, based on market and consumers requirements, project Sam's Club products and logistics precisely to choose the suitable suppliers and monitor to guarantee the quality of goods and services provided to consumers.

According to the conclusion and results, after the SWOT analysis analyzed the reasons for the success of Sam's Club, it shows some similarities and differences with previous opinions. For instance, compared to the research from Johanson and Vahlne in 1977, Sam's Club not only needs to Sam's Club must not only create a connection between internationalization and economy but also need to pay attention to the local government's policies, culture and restrictions on it [7]. Interestingly, Engwall's point of view is the same as Sam's Club in China needs to use local conditions to make changes flexibly. Moreover, in the conclusions and results, it is mainly mentioned that Sam's Club has made various attempts and strategies for consumers. It has also become a strong competitor in the Chinese market. Therefore, behavioural judgments such as consumer behaviour are indispensable when formulating marketing strategies [13]. 


\section{Conclusions}

In conclusion, this paper is based on how the international large-scale warehouse supermarkets in China are gradually decreasing and unsatisfactory, and during this special period of the COVID-19, Wal-Mart's Sam's Club gained a place in China. Hence, this article uses the SWOT analysis of Sam's Club to find and answer the questions of this article by collating various documents on international business and marketing mix. Therefore, Sam's Club's brand's high quality and low price and the impressive economic background give it a great advantage. First of all, Sam's Club has its own brand, and it can decide all the projects. For example, it can choose to control the cost of the product while ensuring the quality of the product. In this way, it will attract more users pursuing high quality and gain more loyal customers. Secondly, Sam's Club will divide more areas and energy for the products that customers prefer to choose to attract target consumers. Furthermore, when a large supermarket intends to enter the Chinese market, it still needs to retain some unique characteristics of its own supermarket while adapting to the local policy and culture. Supermarkets do not need to pursue the market blindly, and some of their own characteristics can be pursued and recognized by many customers. Sam's Club shows its unique charm as an international supermarket. However, the success of Sam's Club is also inseparable from the evaluation and recommendation of many people on the Internet, even if many supermarkets are positively affected by this situation. There are many uncertainties in online evaluation, so it is not reflected in this paper. In the future, Sam's Club needs to combine China's policies to find a more suitable development path and more innovative marketing methods. Secondly, while making more innovations to face a broader range of customers, it is also necessary to maintain the original loyal customers. Therefore, if Sam's Club wants to develop in the long-term in China, it still needs to make many efforts.

\section{References}

[1] Metro. Annual financial statements of Metro AG, 2020. Available at: https://reports.metroag.de/annualreport/2019-2020/index.html. Accessed from: September $18^{\text {th }}, 2021$

[2] Chang, Y. \& Hu, J. Analysis on the Mode of Multinational Retail Enterprises Entering Chinese MarketTake Walmart, Carrefour and Metro as Examples. Modern Economy, 2020, 11:17-2. Doi: 10.4236/me.2020.111003.

[3] Walmart. About us of Sam's Club, 2021. Available at: https://www.samsclub.cn. Accessed from: September $17^{\text {th }}, 2021$

[4] Kim, S., \& Choi, S. The role of warehouse club membership fee in retail competition. Journal Of Retailing, 2007, 83(2), 171-181. DOI: 10.4172/2169-0316.1000239.

[5] Courtemanche, C., \& Carden, A. Competing with Costco and Sam's Club: Warehouse Club Entry and Grocery Prices. Southern Economic Journal, 2014, 80(3): 565-585. DOI:10.4284/0038-4038-2012.135

[6] Zander, Ivo; Mcdougall-covin, Patricia; L Rose, Elizabeth. Journal of International Business Studies; 2015,46(1): 27-35. DOI:10.1057/jibs.2014.60

[7] Vahlne, J. E. \& Johanson, J. New technology, new companies, new business environments and new internationalization processes? Critical perspectives on internationalization, Amsterdam: Pergamon, 1997.

[8] Turnbull, P. W. \& Valla, J. P. Strategies for international, industrial marketing. Business Horizons, 1987, 30:86. DOI: $10.1002 / \mathrm{mde} .4090080107$.

[9] Turner, L. International Affairs. Royal Institute of International Affairs 1944, 49 (3): 450-451 DOI: $10.2307 / 2616854$

[10] Forsgren, M. Theories of the multinational firm: A multidimensional creature in the global economy. Cheltenham, UK: Edward Elgar, 2008.

[11] Dunning, J. H. Location and the Multinational Enterprise: John Dunning's Thoughts on Receiving the "Journal of International Business Studies". Journal of international business studies, 2009, 40 (1): 20-34. DOI: $10.1057 /$ jibs.2008.75

[12] Engwall, L. Global enterprise in the fields of governance. Transnational governance: Institutional dynamics of regulation, Cambridge, MA: Cambridge University Press, 2006. 
[13] Borden, N. The Concept of Marketing Mix. Journal of marketing. New York: Sage Publications, INC, 1984.

[14] Išoraite, M. Marketing Mix Theoretical aspects. International Journal Of Research, 2016, 4(6). DOI: $10.14254 / 1800-5845 / 2019.15-4.10$

[15] Boddy, D. Essentials of Management - A Concise Introduction. Harlow: Pearson. 2012.

[16] Chen, H. SWOT Analysis and Development Strategy of China's Retail Industry. International journal of technology and market, 2017, 18(3):1224. DOI: 10.3390/ijerph18031224.

[17] Sam's Club: Our Company. Available at: https://corporate.samsclub.com/our-company. Accessed from: September $14^{\text {th }}, 2021$

[18] Wang, E. Understanding the 'retail revolution' in urban China: a survey of retail formats in Beijing. The Service Industries Journal, 2011, 31(2): 169-194. DOI:10.1080/02642060802706964.

[19] Munusamy, J., \& Wong, C. Relationship Between Marketing Mix Strategy And Consumer Motive: An Empirical Study In Major TESCO. American: Unitar E-Journal, 2008.

[20] Al Mamun, M., Zakaria, Nahiduzzaman, M., Ahmed, R., \& Rahman, L. On the Transformation of Enterprise Operation Mode in the Era of Cross-border E-commerce - Taking Sam's Club as an Example. Industrial Engineering \& Management, 2017, 06(4). DOI:10.4172/2169-0316.1000239.

[21] Sheth, J. Impact of Covid-19 on consumer behavior: Will the old habits return or die? Journal Of Business Research, 2019, 117:280-283. DOI: 10.1016/j.jbusres.2020.05.059.

[22] Liu, J. Analysis of China's Large Supermarket Service Competition Strategy. Modern Management, 2013, 3:147-151. DOI: 10.12677/MM.2013.35024. 